\title{
New perspective for field measurement of cardiorespiratory parameters in exercising horses
}

\author{
Dominique M. Votion ',2, Isabelle Caudron', Jean-Philippe Lejeune', Laurent van der Heyden', Tatiana Art ${ }^{3}$, Emmanuelle van Erck ${ }^{3}$ \\ and Didier Serteyn ${ }^{1,2}$
}

Equine European Centre of Mont-le-Soie' ${ }^{1}$, Vielsalm, Equine Clinic ${ }^{2}$ and Equine Sports Medicine Centre ${ }^{3}$, University of Liège, Liège, Belgium

\begin{abstract}
Summary
This study aimed at testing the feasibility of using the Cosmed $\mathrm{K} 4 \mathrm{~b}^{2}{ }^{\circledR}$ portable telemetric gas analysis system to record metabolic parameters in ridden exercising horses. Adaptation of the Cosmed $\mathrm{K} 4 \mathrm{~b}^{2}{ }^{\circledR}$ to horses' specificities included the design of an airtight face-mask $\left(\right.$ Equimask $^{\circledR}$ ) adapted to a hackamore bridle to allow ridding the horse. The portable system enables the recording of tidal volume (VT), respiratory rate (RR), minute expired volume (VE), pulmonary oxygen uptake $\left(\mathrm{VO}_{2}\right)$, carbon dioxide delivery $\left(\mathrm{VCO} \mathrm{O}_{2}\right)$, heart rate $(\mathrm{HR})$ and speed. Four saddle horses equipped with the system completed 3 treadmill tests (TT1 to TT3) and 1 field test (FT) consisting of galloping phases at incremental speeds. Horses were sampled for blood lactate (LA) during the tests. The successive treadmill tests showed the influence of stress on measurements: with horses becoming accustomed to treadmill, LA and HR were reduced between TT1 and TT3. As VO 2 is related to cardiovascular function, influence of stress resulted in higher $\mathrm{VO}_{2}$ in TT1 vs. TT3. The $\mathrm{VO}_{2}$ reached at maximal speed during treadmill tests was lower than the expected maximal aerobic power $\left(\mathrm{VO}_{2 \mathrm{max}}\right)$ for trained saddle horses. During $\mathrm{FT}$, the $\mathrm{VO}_{2}$ reached at the final gallop was lower than the $\mathrm{VO}_{2}$ recorded during any of the treadmill tests thus reflecting the increasing difficulty to reach $\mathrm{VO}_{2 \max }$ with ridden horses in field conditions. This study demonstrated that cardiorespiratory parameters may be obtained in ridden horses during a field trial and opens new perspectives in the follow-up of sport horses in real field conditions.
\end{abstract}

Keywords: horse, exercise, pulmonary oxygen uptake, field testing, portable metabolic system, Cosmed K4 $b^{2}$

\section{Neue Perspektiven zur Feldmessung kardiorespiratorischer Parameter beim arbeitenden Pferd}

Die maximale aerobe Kapazität oder $\mathrm{VO}_{2 \max }$ stellt einen wichtigen Wert zur Bestimmung der Fitness dar. Bis heute sind Messungen zur pulmonalen Sauerstoffaufnahme $\left(\mathrm{VO}_{2}\right)$ und $\mathrm{VO}_{2 \max }^{2 \max }$ am arbeitenden Pferd nur unter Laborbedingungen möglich. Seit kurzem steht Cosmed K4 $\mathrm{b}^{2 \AA}$, ein portables telemetrisches Gasanalysesystem für den Einsatz am arbeitenden Pferd zur Verfügung. Ziel der Studie war die Prüfung dessen Einsatzfähigkeit für metabolische Messungen am Pferd unter dem Reiter. Zur Anpassung von Cosmed K4 $b^{2 \circledast}$ an die spezifischen Bedingungen beim Pferd wurde eine luftdicht abschließende Atemmaske entwickelt (Equimask ${ }^{\circledR}$ ) und diese mit einem Hackamore-Halfter verbunden. Zwei Öffnungen innerhalb der Maske erlauben den Durchfluss der Atemluft durch 2 Turbinen, über die Messungen des Atemzugvolumens (VT), der Atemfrequenz (RR) und des Expirationsminutenvolumens (VE) möglich sind. Proben der Expirationsgase werden an einer der Turbinen entnommen und in der portablen Cosmed $\mathrm{K}_{4} \mathrm{~b}^{2 \otimes}$-Messeinheit, die an der Brustwand des Pferdes fixiert wird, auf den Gehalt an $\mathrm{O}_{2}$ and $\mathrm{CO}_{2}$ analysiert. Die tragbare Einheit zeichnet metabolische Parameter ebenso wie die Herzfrequenz (HR) und Geschwindigkeit auf. Vier gesunde und trainierte Military-Pferde, ausgerüstet mit dem portablen Messsystem, absolvierten innerhalb von 3 Wochen 3 Laufband-Stufentests (TT1 to TT3) und einen Feldtest (FT). Der Laufbandtest bestand aus einer Aufwärmphase gefolgt von 2 Minuten Galopp bei 7, $8 \mathrm{~m} / \mathrm{sec}$ (TT1) und $9 \mathrm{~m} / \mathrm{sec}$ (TT2 and TT3). Beim Feldtest wurden die Pferde nach einem Warmup zweimal in einem Reitpaddock galoppiert. Bei allen Test wurden den Pferden jeweils unmittelbar nach den Galoppphasen Blut für den Laktatnachweis (LA) entnommen. Der Zeitverlauf der kardiorespiratorischen Parameter während des Stufentests auf dem Laufband zeigte den Einfluss des Stresses auf die Messungen: Im Verlauf der Gewöhnung der Pferde an das Laufband zwischen TT1 und TT3 sanken LA and $\mathrm{HR}$. Da VO⿰亻 2 von allen Systemen zur $\mathrm{O}_{2}$-Versorgung und damit von der kardiovaskulären Funktion abhängig ist, resultiert der Stresseinfluss in einem höheren $\mathrm{VO}_{2}$ bei TT1 im Vergleich mit TT3. VO $\mathrm{O}_{2}$ war bei maximaler Geschwindigkeit auf dem Laufband geringer als das erwartete $\mathrm{VO}_{2 \max }$ der Pferde unter dem Sattel. Beim Feldtest war $\mathrm{VO}_{2}$ beim letzten Galopp niedriger als jeder beim Laufbandtest gemessene $\mathrm{VO}_{2}$-Wert. Dies zeigt wieder die Schwierigkeit auf, beim Pferd unter dem Reiter unter Feldbedingungen $\mathrm{VO}_{2 \max }$ zu erreichen. Der errechnete Respirationsquotient (RQ) war bei jeder Geschwindigkeit mit den physiologischen Werten inkompatibel, was darauf hinweist, dass das Systen die $\mathrm{CO}_{2}$-Versorgung beim arbeitenden Pferd nicht exakt messen kann. Die Ergebnisse der Untersuchung zeigen, dass beim Pferd unter dem Reiter unter Feldbedingungen kardiorespiratorische Parameter gemessen werden können. Die Ergebnisse zeigen auch die Notwendigkeit, 1. zur Stressreduzierung die Pferde an die Testbedingungen zu gewöhnen, 2. hoch standardisierte Test zu verwenden, um $\mathrm{VO}_{2}$ in Abwesenheit von $\mathrm{VO}_{2 \text { max }}$ verlässlich interpretieren zu können und 3. zur Beurteilung der Kondition von Pferden unter dem Reiter unter Feldbedingungen auf einen anderen physiologischen Parameter als $\mathrm{VO}_{2 \max }$ auszuweichen. Die Studie eröffnet bei der Verlaufsuntersuchung von Pferden neue Perspektiven bezüglich der Bewertung der Anpassung an Training und Kondition unter Feldbedingungen.

Schlüsselwörter: Leistung, Sauerstoffaufnahme, pulmonal, Feldtest, portables Messsystem, Cosmed K4 b²

\section{Introduction}

In the exercising horse, the oxygen delivery to the muscle enables the regeneration of high-energy phosphates (ATP) which are necessary for sustaining an effort and for subsequent recovery. For a fixed and constant level of submaximal exercise, the pulmonary oxygen uptake $\left(\mathrm{VO}_{2}\right)$ reflects a balance between the energy required by the working muscles and ATP production via the aerobic metabolism. In horses performing 
high-intensity maximal exercise, it is, in fine, the cells of the locomotory muscles that determine the demand in oxygen because over $90 \%$ of the energy spent is dedicated to muscle cells (Hoppeler and Weibel 1998). The point at which $\mathrm{VO}_{2}$ plateaus and shows no further increase with additional workload corresponds to the maximal aerobic power, or $\mathrm{VO}_{2 \text { max }}$. The $\mathrm{VO}_{2 \max }$ is an important variable that sets the upper limit for submaximal performance and thus correlates to athletic performance in horses (Harkins et al. 1993, Gauvreau et al. 1995). Study of the metabolic response to exercise has proved to be of great value to determine fitness as well as to study the effects of training or detraining in sport horses (Seeherman and Morris 1990, Art and Lekeux 1993, Betros et al. 2002, Ohmura et al. 2002). To the authors' knowledge, up to now, $\mathrm{VO}_{2}$ and $\mathrm{VO}_{2 \text { max }}$ measurements in exercising horses have been limited to treadmill tests because the gas analyzer used to measure $\mathrm{VO}_{2}$ and carbon dioxide delivery $\left(\mathrm{VCO}_{2}\right)$ required a heavy stationary apparatus. Therefore, field testing of sport horses has usually been based on heart rate $(\mathrm{HR})$ and blood lactate (LA) determination without any direct evaluation of respiratory components (Kobayashi et al. 1999, Courouce et al. 2002, Davie et al. 2002). In human sport medicine, metabolic parameters during field testing may be evaluated using the commercially available Cosmed $\mathrm{K} 4$ b2 ${ }^{\circledR}, 1$ portable telemetric gas analysis system (Laconi et al. 1998, Doyon et al. 2001, Thomas et al. 2005) which has been validated in human (Duffield et al. 2004). Recently, the system has been adapted to horses and the validity of the measured parameters has been controlled (Art et al. 2006). The purpose of this study was to examine the feasibility of metabolic measurement to record physiologically significant parameters in ridden exercising horses.

\section{Materials and methods}

\section{The portable metabolic measurement system}

Adaptation of the $\mathrm{K} 4 \mathrm{~b}^{2{ }^{\circledR, 1}}$ to horses' specificities included the design of an airtight face-mask (Equimask ${ }^{\circledR, 2}$; Figure 1). The Equimask ${ }^{\circledR, 2}$ is a lightweight preformed plastic mask that contains internal pieces of foam to allow a snug fitting over the horse's muzzle. A silicone rubber gasket ensures an airtight seal and can be fastened with external straps. The Equimask ${ }^{\circledR, 2}$ is adapted to a hackamore bridle that allows ridding the horse whilst maintaining the mask airtight. The dead space in the mask is around $0.5 \mathrm{~L}$ (Art et al. 2006). Two openings in the mask, facing each nostril, direct the transit of respiratory airflow through 2 bidirectional turbines (internal diameter: $60 \mathrm{~mm}$ ). Rotation of the turbines with airflow is measured by an opto-electronic reader that counts the revolutions/sec. The $\mathrm{K} 4 \mathrm{~b}^{2 \otimes, 1}$ portable unit integrates this information to calculate the tidal volume (VT), respiratory rate (RR) and minute expired volume (VE). Lung volumes and flows are given in BTPS conditions. The expired gases are sampled at the level of one of the turbines and collected in the portable unit strapped to the horse's chest wall via a sampling line (Nafion ${ }^{\circledR, 3}$ tubing). The collected gases are analysed for $\mathrm{O}_{2}$ and $\mathrm{CO}_{2}$ content. The oxygen-polarographic zirconium cell-analyser (range 7-24\%; accuracy: $\pm 0.02 \%$ ) and the infrared nondispersive thermostatically controlled carbon dioxide analyser (range 0.0-8.0\%; accuracy: $\pm 0.01 \%$ ) measure the end tidal $\mathrm{O}_{2}\left(\mathrm{FETO}_{2}\right)$ and $\mathrm{CO}_{2}\left(\mathrm{FETCO}_{2}\right)$ fractions, respectively. The portable unit, powered by a rechargeable battery, records metabolic parameters as well as HR (Heart rate Polar Equine Transmitter ${ }^{\circledR, 4}$ ) and speed owing to a GPS system (GPS Autolocate $^{T M, 5}$; horizontal accuracy: $<15$ meters).

Before each use, the $\mathrm{O}_{2}$ and $\mathrm{CO}_{2}$ analysers were calibrated with ambient air (assuming $\mathrm{O}_{2}$ and $\mathrm{CO}_{2}$ fractional contents of $20.9 \%$ and $0.03 \%$, respectively) and $\mathrm{a} \mathrm{O}_{2}-\mathrm{CO}_{2}$ mixture with definite concentrations $\mathrm{O}_{2}$ and $\mathrm{CO}_{2}$ fractional contents of $15 \%$ and $5 \%$, respectively). The delay between airflow and gas signal was measured using the sampling line utilized

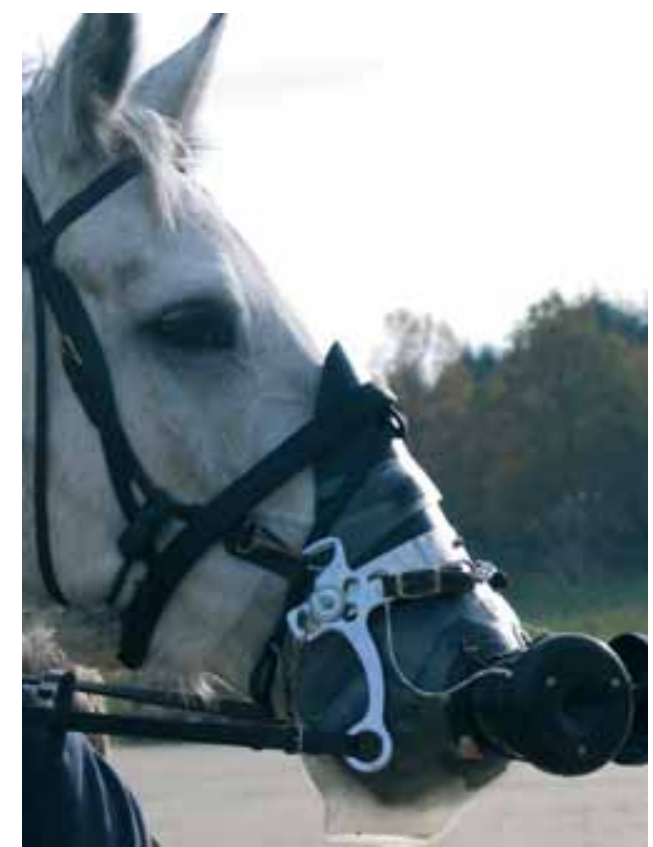

Fig 1 Photograph of a horse wearing the Equimask ${ }^{\circledR}$. This mask especially designed for horses is a lightweight preformed plastic mask adapted to a hackamore bridle that allows ridding the horse whilst maintaining the system airtight. Two bidirectional turbines facing each nostril enable measurement of respiratory parameters. Expired gases are sampled at the level of one of the turbines to be analysed for $\mathrm{O}_{2}$ and $\mathrm{CO}_{2}$ in a portable unit strapped to the horse's chest wall.

Pferd mit Equimask ${ }^{\circledR}$. Die Maske wurde speziell für Pferde entwickelt, eine leichte Kunststoffmaske, adaptiert an ein Hackemore-Halfter, was die Messung unter dem Reiter ermöglicht. Zwei gegenläufige Turbinen über jeder Nüster ermöglichen die Messung respiratorischer Parameter. Proben der Expirationsgase werden im Bereich einer der Turbinen entnommen und in der portablem Messeinheit, die an der Brustwand des Pferdes fixiert ist, auf $\mathrm{O}_{2}$ und $\mathrm{CO}_{2}$ analysiert.

during the test protocol. According to the manufacturer, no volume calibration is required prior to the test. The accuracy of volume measurement is regularly checked by the manufacturer during routine maintenance of the system (at least twice a year). However, it must be specified that this check is performed using 3, 5 and $7 \mathrm{~L}$-syringes of air sent at 20 and 40 pulses per minute to the system.

\section{Experimental protocol}

Four healthy trained military horses (weight $=546.3 \pm 51.8$ $\mathrm{kg}$, age $=6.4 \pm 0.1 \mathrm{yr}$; [means $\pm \mathrm{SD}$ ]; 2 geldings and 2 females) were used. Each horse was equipped with the adapted portable system and completed 3 incremental treadmill tests (TT1 to TT3) and 1 field test (FT) within 3 weeks. The treadmill tests 
consisted of a warm-up period (5-min walk [1.5 m/sec] and 5 $\mathrm{min}$ trot [ $4 \mathrm{~m} / \mathrm{sec}]$ ) followed by galloping for $2 \mathrm{~min}$ at 7 and 8 $\mathrm{m} / \mathrm{sec}$ during TT 1 and for $2 \mathrm{~min}$ at 7,8 and $9 \mathrm{~m} / \mathrm{sec}$ during TT2 and TT3. For FT, ridden horses were galloped twice for 2 min in a large ridding paddock $(80 \times 60$ m) after a warm-up period (Figure 2). The speed of the second gallop corresponded to the maximum speed that could be subjectively and reasonably attained by the rider with each horse in these specific field conditions (i.e. wearing a facemask and galloping in a paddock). The speeds attained during FT were calculated by the GPS system and checked by manual chronometry.

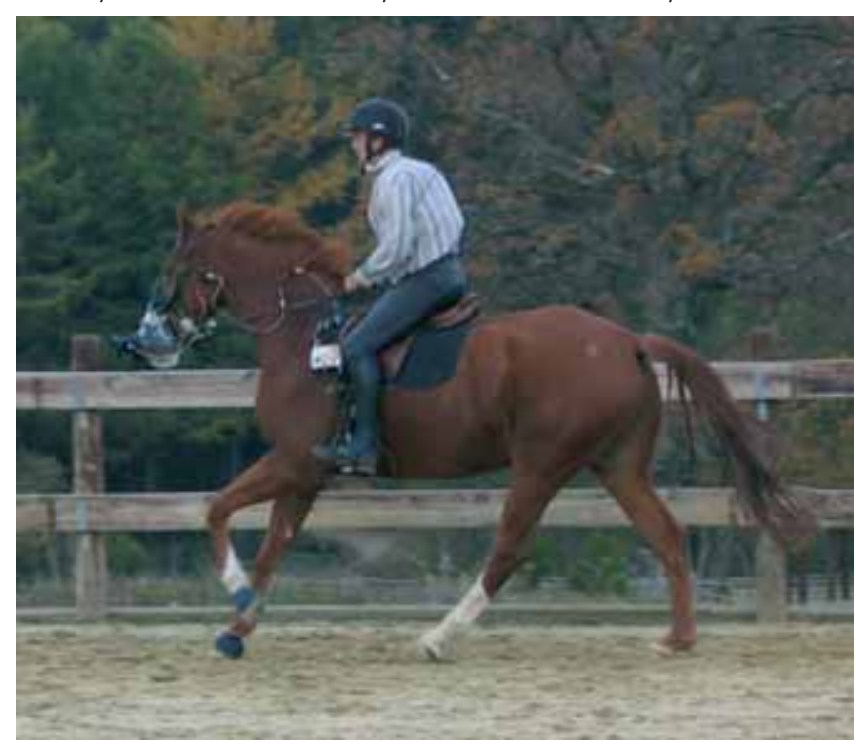

Fig 2 Photograph of a horse galloping with Equimask ${ }^{\circledR}$ und Cosmed $\mathrm{K} 4 \mathrm{~b}^{2}{ }^{\circledR}$ during the field test.

Pferd mit Equimask ${ }^{\circledR}$ und Cosmed $\mathrm{K} 4 \mathrm{~b}^{2}{ }^{\circledR}$ während des Feldtests

Cardiorespiratory measurements were collected continuously throughout the tests. Horses' blood was sampled within 15 sec following each gallop for determination of LA using a portable lactate analyzer (Accutrend $\left.{ }^{\circledR, 6}\right)$.

\section{Data analysis}

The respiratory coefficient (RQ) was calculated by dividing $\mathrm{VCO}_{2}$ by $\mathrm{VO}_{2}$ on a breath-by-breath basis. Results of the breath-by-breath data, HR and running speed (during FT) collected during the last minute of each step were averaged. This study did not aim to compare the acquired parameters under different experimental conditions (e.g. treadmill tests vs. FT) but to challenge the feasibility of using the described technology to field testing. Therefore, no statistical analysis was applied to the data. In addition, the small number of subjects $(n=4)$ impedes valid statistical analysis.

\section{Results}

Time-course of breath-by-breath values for $\mathrm{VO}_{2}$ and $\mathrm{HR}$ are shown graphically for a representative FT of one horse in Figure 3. Mean ( \pm SD) running speeds, LA and HR recorded during the treadmill tests and FT are presented in Table 1. Mean ( \pm SD) breath-by-breath values for RR, VT, VE VO, $\mathrm{VCO}_{2}$ and $\mathrm{RQ}$ are presented in Tables 2 and 3 .
All horses completed the treadmill tests and FT satisfactorily. Time-course of cardiorespiratory parameters during the successive treadmill tests showed reduced LA and HR at 8 and 9 $\mathrm{m} / \mathrm{sec}$ galloping speeds whereas higher $\mathrm{VO}_{2}$ and $\mathrm{VCO}_{2}$ were found in TT1 vs. TT3. During FT, the mean ( \pm SD) galloping speeds attained were $5.7 \pm 0.3 \mathrm{~m} / \mathrm{sec}$ (1 st gallop) and 6.2 $\pm 0.4 \mathrm{~m} / \mathrm{sec}$ (2nd gallop) with maximal peak of $7.2 \pm 0.5$ $\mathrm{m} / \mathrm{sec}$. The speeds given by the GPS system were slightly lower than the ones calculated by chronometry (data not shown). The $\mathrm{VO}_{2}$ reached at the final gallop was lower than the $\mathrm{VO}_{2}$ recorded during any of the treadmill tests. The cal-

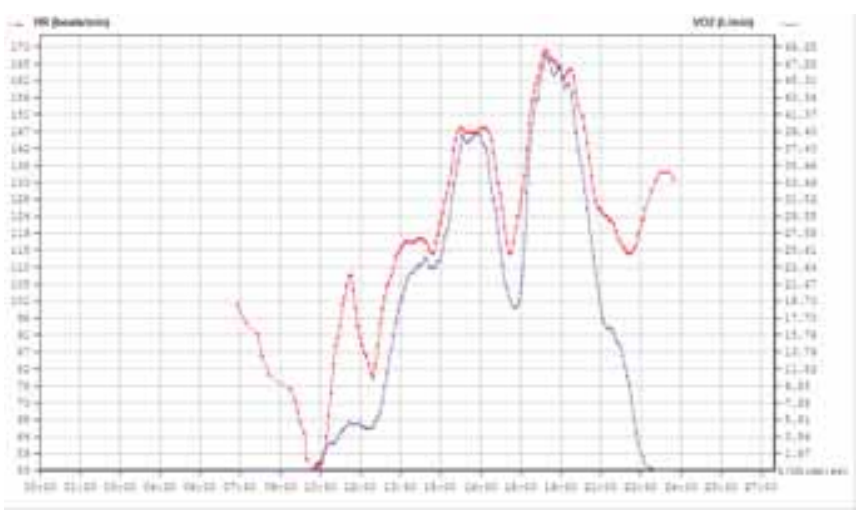

Fig 3 Heart rate and pulmonary oxygen uptake $\left(\mathrm{VO}_{2}\right)$ recorded over time $(t)$ during a field test with one representative horse. The $\mathrm{VO}_{2}$ is expressed in $\mathrm{L} / \mathrm{min}$ without taking into account the weight of the horse as opposed to the data in Table 3 where $\mathrm{VO}_{2}$ is expressed in $\mathrm{ml} / \mathrm{kg} / \mathrm{min}$.

Herzfrequenz $(H R)$ und pulmonale Saverstoffaufnahme $\left(\mathrm{VO}_{2}\right)$ über die Zeit ( $t$ ) während eines Feldtests bei einem repräsentativen Pferd. $\mathrm{VO}_{2}$ ist in $\mathrm{I} / \mathrm{min}$ ausgedrückt ohne Berücksichtigung des Pferdegewichts im gegensatz zu den Werten in Tabelle 3, die in $\mathrm{ml} / \mathrm{kg} / \mathrm{min}$ ausgedrückt sind.

culated RQ at any speed (except during walk; data not shown) was incompatible with physiologic data.

\section{Discussion}

Reliability of the system

The bi-annual calibration of the volume performed by the K4 $\mathrm{b}^{2 \otimes, 1}$ manufacturer mimics a maximal VE of $280 \mathrm{~L} / \mathrm{min}$ which is far below the $1,500 \mathrm{~L} / \mathrm{min}$ that may be reached during high-intensity exercise in horses (Art et al. 1990, Art and Lekeux 1995). However, the $\mathrm{K} 4 \mathrm{~b}^{2 \circledR}$ has proven to reliably measure VE even at high workloads (Art et al. 2006). The consistency of metabolic measurements has been confirmed for all the parameters described in our study except for measurement of $\mathrm{VCO}_{2}$ which tended to be underestimated most probably because the response-time of the infra-red analyser that measures $\mathrm{FETCO}_{2}$ was to slow at high RR (Art et al. 2006). In our study, the calculated RQ (from 0.4 to 0.6 ) were too low as compared to physiological data thus confirming the unreliability of the $\mathrm{VCO}_{2}$ measurement with the $\mathrm{K} 4 \mathrm{~b}^{2 \circledR}$ in exercising horses.

The GPS system tended to underestimate the speeds of horses during FT. This is most probably explained by the accuracy of the system which would prevent precise determination of the speed in horses moving in a small area. 
Table 1 Mean \pm SD $(n=4)$ speed, lactatemia $(L A)$ and heart rate $(H R)$ recorded during 3 incremental treadmill tests $(T T 1$ to $T T 3)$ and 1 field test $(F T)$. Mittlere $\pm S D(n=4)$ Geschwindigkeit, Blutlaktat (LA) und Herzfrequenz (HR) während 3 Laufband-Stufentests (TT1 to TT3) und 1 Feldtest (FT).

\begin{tabular}{|c|c|c|c|c|c|c|c|c|c|c|c|c|}
\hline \multirow[t]{2}{*}{ Gait } & \multicolumn{4}{|c|}{ Speed (m/sec) } & \multicolumn{4}{|c|}{ LA (mmol/L) } & \multicolumn{4}{|c|}{ HR (beats/min) } \\
\hline & TT1 & TT2 & TT3 & FT & TT1 & TT2 & TT3 & FT & TT1 & TT2 & TT3 & FT \\
\hline \multirow[t]{2}{*}{$\mathrm{T}$} & 4.0 & 4.0 & 4.0 & 3.5 & $=-$ & $\ldots$ & $\ldots$ & $\ldots$ & 137.4 & 132.9 & 77.8 & 141.3 \\
\hline & \pm 0.0 & \pm 0.0 & \pm 0.0 & \pm 0.5 & -- & -- & --- & -- & \pm 23.3 & \pm 35.1 & \pm 28.6 & \pm 21 \\
\hline \multirow[t]{2}{*}{ Gl } & 7.0 & 7.0 & 7.0 & 5.7 & 4.4 & 2.3 & 3.1 & 1.9 & 181.3 & 148.9 & 153.3 & 163.2 \\
\hline & \pm 0.0 & \pm 0.0 & \pm 0.0 & \pm 0.3 & \pm 2.6 & \pm 0.7 & \pm 1.4 & \pm 0.3 & \pm 21.3 & \pm 20.3 & \pm 8.6 & \pm 14.5 \\
\hline \multirow[t]{2}{*}{ G2 } & 8.0 & 8.0 & 8.0 & 6.2 & 3.9 & 2.3 & 2.0 & 2.4 & 172.4 & 151.0 & 131.1 & 167.1 \\
\hline & \pm 0.0 & \pm 0.0 & \pm 0.0 & \pm 0.4 & \pm 1.7 & \pm 0.4 & \pm 0.5 & \pm 0.6 & \pm 27.5 & \pm 26 & \pm 34.4 & \pm 6.1 \\
\hline \multirow[t]{2}{*}{ G3 } & -- & 9.0 & 9.0 & $\ldots$ & $\ldots$ & 2.8 & 2.5 &.- & $\ldots$ & 165.0 & 162.9 & $\ldots$ \\
\hline &.- & \pm 0.0 & \pm 0.0 & $\ldots$ & $\ldots$ & \pm 0.3 & \pm 0.5 & $\ldots$ & $\ldots$ & \pm 7.7 & \pm 5.2 & $\ldots$ \\
\hline
\end{tabular}

T: trot; G1: $1^{\text {st }}$ gallop; G2: $2^{\text {nd }}$ gallop and G3: $3^{\text {rd }}$ gallop.

Table 2 Mean $\pm S D(n=4)$ respiratory rate $(R R)$, tidal volume $(V T)$ and minute expired volume $(V E)$ recorded during 3 incremental treadmill tests (TT1 to TT3) and 1 Field test (FT).

Mittlere $\pm S D(n=4)$ Respirationsrate (RR), Atemzugsvolumen (VT) und expiratorisches Minutenvolumen (VE) während 3 Laufband-Stufentests (TT1 to TT3) und 1 Feldtest (FT).

\begin{tabular}{|c|c|c|c|c|c|c|c|c|c|c|c|c|}
\hline \multirow[t]{2}{*}{ Gait } & \multicolumn{4}{|c|}{ RR (breaths/min) } & \multicolumn{4}{|c|}{$\mathrm{V}_{\mathrm{T}}(\mathrm{L})$} & \multicolumn{4}{|c|}{$V_{E}(L / m i n)$} \\
\hline & $\mathrm{TT} 1$ & TT2 & TT3 & FT & TT1 & TT2 & TT3 & FT & $\mathrm{TT} 1$ & TT2 & TT3 & FT \\
\hline \multirow[t]{2}{*}{$\mathrm{T}$} & 71.4 & 68.1 & 62.9 & 87.6 & 11.8 & 11.5 & 11.4 & 10.9 & 771.3 & 761.1 & 702.4 & 899.0 \\
\hline & \pm 27.2 & \pm 13.3 & \pm 11.4 & \pm 7.2 & \pm 2.1 & \pm 1.4 & \pm 0.8 & \pm 1.0 & \pm 82.1 & \pm 118.6 & \pm 64.9 & \pm 80.2 \\
\hline \multirow{2}{*}{ Gl } & 99.6 & 107.8 & 105.9 & 106.1 & 14.6 & 11.9 & 12.7 & 12.9 & 1394.7 & 1264.6 & 1326.8 & 1359.8 \\
\hline & \pm 14.4 & \pm 5.3 & \pm 6 & \pm 2.7 & \pm 2.1 & \pm 1.3 & \pm 1.6 & \pm 0.4 & \pm 143.1 & \pm 118.2 & \pm 200.7 & \pm 10.5 \\
\hline \multirow[t]{2}{*}{ G2 } & 110.8 & 111.0 & 108.2 & 109.3 & 12.9 & 12.6 & 12.8 & 13.7 & 1417.2 & 1395.1 & 1375.6 & 1498.8 \\
\hline & \pm 4.1 & \pm 3.6 & \pm 4.5 & \pm 4.2 & \pm 1.7 & \pm 1.5 & \pm 1.5 & \pm 0.9 & \pm 151.5 & \pm 136.2 & \pm 105.4 & \pm 41.3 \\
\hline \multirow[t]{2}{*}{ G3 } & -. & 110.6 & 110.7 & $=-$ & -.. & 13.7 & 12.7 & $=-$ & -- & 1501.7 & 1393.3 & -.. \\
\hline & $\ldots$ & \pm 3.0 & \pm 5.0 & $\ldots$ & $\ldots$ & \pm 0.9 & \pm 1.7 &.- & $\ldots$ & \pm 78.4 & \pm 166.2 & $\ldots$ \\
\hline
\end{tabular}

T: trot; G1: $1^{\text {st }}$ gallop; G2: $2^{\text {nd }}$ gallop and G3: $3^{\text {rd }}$ gallop.

Table 3 Mean $\pm \mathrm{SD}(\mathrm{n}=4)$ pulmonary oxygen uptake $\left(\mathrm{VO}_{2}\right)$ and carbon dioxide delivery $\left(\mathrm{VCO}_{2}\right)$ measured during 3 incremental treadmill tests (TT1 to TT3) and 1 field test (FT) and the calculated respiratory quotient (RQ) for each test.

Mittlere $\pm S D(n=4)$ pulmonale Saverstoffaufnahme $\left(\mathrm{VO}_{2}\right)$ und Kohlendioxidabgabe $\left(\mathrm{VCO}_{2}\right)$ während 3 Laufband-Stufentests (TT1 to TT3) und 1 Feldtest (FT) und der errechnete Respirationsquotient (RQ) für jeden Test.

\begin{tabular}{|c|c|c|c|c|c|c|c|c|c|c|c|c|}
\hline \multirow[t]{2}{*}{ Gait } & \multicolumn{4}{|c|}{$\mathrm{VO}_{2}(\mathrm{ml} / \mathrm{kg} / \mathrm{min})$} & \multicolumn{4}{|c|}{$\mathrm{VCO}_{2}(\mathrm{ml} / \mathrm{kg} / \mathrm{min})$} & \multicolumn{4}{|c|}{$R Q$} \\
\hline & TT1 & TT2 & TT3 & FT & TT1 & TT2 & TT3 & FT & TT1 & TT2 & TT3 & FT \\
\hline \multirow[t]{2}{*}{$\mathrm{T}$} & 44.5 & 37.8 & 41.5 & 40.2 & 29.3 & 21.7 & 24.8 & 21.2 & 0.6 & 0.6 & 0.6 & 0.5 \\
\hline & \pm 10.1 & \pm 2.0 & \pm 8.2 & \pm 7.0 & \pm 13.9 & \pm 4.8 & \pm 6.6 & \pm 5.4 & \pm 0.2 & \pm 0.1 & \pm 0.1 & \pm 0.2 \\
\hline \multirow[t]{2}{*}{ G1 } & 99.1 & 77.4 & 91.1 & 67.0 & 65.0 & 36.9 & 45.9 & 38.6 & 0.6 & 0.5 & 0.5 & 0.6 \\
\hline & \pm 21.4 & \pm 18.6 & \pm 29.4 & \pm 9.4 & \pm 29.1 & \pm 16.2 & \pm 17.5 & \pm 15.3 & \pm 0.2 & \pm 0.1 & \pm 0.1 & \pm 0.2 \\
\hline \multirow[t]{2}{*}{ G2 } & 90.5 & 81.6 & 76.6 & 75.8 & 52.7 & 36.2 & 34.7 & 41.3 & 0.6 & 0.4 & 0.5 & 0.6 \\
\hline & \pm 17.8 & \pm 14.2 & \pm 2.4 & \pm 16.2 & \pm 23.8 & \pm 15.1 & \pm 3.6 & \pm 12.9 & \pm 0.2 & \pm 0.1 & \pm 0.1 & \pm 0.3 \\
\hline \multirow[t]{2}{*}{ G3 } &.- & 81.6 & 81.3 & $\ldots$ & $\ldots$ & 31.5 & 34.4 & $\ldots$ &.- & 0.4 & 0.4 & -. \\
\hline & $\ldots$ & \pm 11.7 & \pm 3.8 & $\ldots$ & $\ldots$ & \pm 12 & \pm 4.3 & $\ldots$ & $\ldots$ & \pm 0.1 & \pm 0.1 & $\ldots$ \\
\hline
\end{tabular}

T: trot; G1: $1^{\text {st }}$ gallop; G2: $2^{\text {nd }}$ gallop and G3: $3^{\text {rd }}$ gallop.

Influence of stress

Time course of cardiorespiratory parameters during the successive treadmill tests showed the influence of stress on mea- surements: with horses becoming accustomed to treadmill, LA and HR were significantly reduced between TT1 and TT3 at each galloping speed. As $\mathrm{VO}_{2}$ is related to all systems involved in $\mathrm{O}_{2}$ supply and thus to cardiac output (Jones and Lind- 
stedt 1993, Hoppeler and Weibel 1998), influence of stress resulted in higher $\mathrm{VO}_{2}$ in TT1 vs. TT3 at each gallop. This observation highlights the necessity to acclimatize horses to the face mask and test procedures in order to reduce the influence of stress on the measured parameters.

\section{Reaching $\mathrm{VO}_{2 \max }$ with saddle horses}

Oxidative metabolism is the principal means of the organism to generate energy. The $\mathrm{VO}_{2 \max }$ is the best parameter to estimate aerobic capacity because at $\mathrm{VO}_{2 \text { max }}$, the oxygen cascade (from respiratory system to mitochondria, see further) is saturated at one or several steps (the strongest determinant of $\mathrm{VO}_{2 \text { max }}$ being the capacity of the cardiovascular system to transport oxygen; Poole 2004). Therefore, $\mathrm{VO}_{2 \max }$ measurement demonstrates a better reproducibility as compared to other estimates of maximal aerobic capacity (e.g. maximal $\mathrm{HR}$ [HRmax], velocity at a HR of 200 beats $/ \mathrm{min}\left[\mathrm{V}_{200}\right], \mathrm{VO}_{2}$ at a HR of 200 beats/min $\left[\mathrm{VO}_{2-200}\right], \mathrm{VO}_{2}$ at $\mathrm{HR}_{\text {max }}\left[\mathrm{VO}_{2-\mathrm{HR}_{\max }}\right]$, work rate at a HR of 200 beats/min [ $\mathrm{W}_{200}$ ], work rate at HRmax [W-HRmax], LA threshold [i.e. the point at which an accelerated increase in LA concentration is noted] ...) which were found to be less precise (Evans and Rose 1988). At the highest level of treadmill exercise $(9 \mathrm{~m} / \mathrm{s})$ the $\mathrm{VO}_{2}$ reached $(81.5 \pm 7.8 \mathrm{ml} / \mathrm{min} / \mathrm{kg}$; mean \pm SD for TT2 and TT3) was lower than the expected $\mathrm{VO}_{2 \max }$ (above $100 \mathrm{ml} / \mathrm{min} / \mathrm{kg}$ ) for trained sport horses (Evans and Rose 1988). During FT, the mean run speeds at gallop were below the lowest galloping speed of the treadmill tests. Therefore, the $\mathrm{VO}_{2}$ reached at the final gallop $(75.8 \pm 16.2 \mathrm{ml} / \mathrm{min} / \mathrm{kg}$; mean $\pm \mathrm{SD})$ was lower than any of the values obtained at gallop during the treadmill tests thus reflecting the increasing difficulty to reach $\mathrm{VO}_{2 \max }$ with ridden horses in field conditions.

\section{Measuring $\mathrm{VO}_{2}$}

In the absence of $\mathrm{VO}_{2 \max }$ determination, assessment of fitness in sport horses must rely on other cardiorespiratory parameters. Aerobic capacity depends both on the availability of oxygen and the ability of muscle tissue to use that oxygen for energy. At $\mathrm{VO}_{2 \mathrm{max}^{\prime}}$ the oxygen uptake may be considered as allotted to locomotory muscle cells (Hoppeler and Weibel 1998). On the other hand, the physiological significance of $\mathrm{VO}_{2}$ under the level of maximal and a fortiori submaximal exercise must be interpreted with caution. The $\mathrm{VO}_{2}$ is intimately linked to the systems required for supply (respiratory tract and lungs, RR, VT, alveolar-capillary membrane ...), transport (haemoglobin concentration ...), delivery (blood volume, cardiac output, peripheral blood flow, muscle capillarization, diffusive capacity at the capillary-myocyte interface ...) and utilisation (mitochondrial density, aerobic metabolism, ...) of oxygen. Therefore, external factors that interfere with one of the component of the respiratory cascade influence $\mathrm{VO}_{2}$ especially when these factors act on the cardiovascular system. Stress and anxiety acting on the cardiac function are an example and the variation in HR observed during the successive treadmill tests performed in this study are a good illustration of the impact of these factors. Other examples of external factors may be found in the literature such as the effect of body incline on cardiac output (McDonough et al. 2002a) and $\mathrm{VO}_{2}$ (Eaton et al. 1995, McDonough et al. $2002 b$ ) or such as the effect of hot and humid conditions on aerobic metabolism (Art et al. 1995). Carefully controlled conditions and adequate preparation of the horse to test procedures are a prerequisite to correct interpretation of $\mathrm{VO}_{2}$ data.

In addition, the $\mathrm{VO}_{2}$ kinetics (the rate at which $\mathrm{VO}_{2}$ adjusts to meet the new energy demand at the transition from one metabolic rate to another, Poole et al. 2004) imposes that $\mathrm{VO}_{2}$ measurements in field trials are performed under controlled timing, ideally after attainment of an equilibrium corresponding to a constant load of exercise. The equine pulmonary $\mathrm{VO}_{2}$ response following the onset of exercise has been characterised (Langsetmo et al. 1997). The $\mathrm{VO}_{2}$ response to an exercise at constant work-rate depends on its intensity: at moderate levels of exercise (below LA threshold), the $\mathrm{VO}_{2}$ steady state is achieved within $60 \mathrm{sec}$ whereas at heavy exercise levels (above the LA threshold), the initial $\mathrm{VO}_{2}$ fast response is markedly slowed down and followed by a secondary slow component of $\mathrm{VO}_{2}$ which prevents attainment of a $\mathrm{VO}_{2}$ plateau. This slow component is initiated within 2.5 min after exercise transition and is superimposed on the initial response. This slow component elevates $\mathrm{VO}_{2}$ above that predicted from exercise below LA threshold or from the $\mathrm{VO}_{2}$ speed relationship determined during incremental exercise. Thus, accurate interpretation of $\mathrm{VO}_{2}$ measurement is dependent on determination of level of exercise (i.e. using LA determination) and precise timing of $\mathrm{VO}_{2}$ data acquisition. In field trials where $\mathrm{VO}_{2 \text { max }}$ may not be achieved, constant moderate exercise level might be a good alternative to define aerobic capacity under specific conditions.

New perspectives for exercise testing in the field

The portable metabolic system opens new perspectives for studying cardiorespiratory dynamics in horses as they carry out exercise in genuine field conditions. This system might be used to study the metabolic changes and energy cost induced by equestrian equipment/ harnessing (e.g. tension of the girth strap, draw or running reins, Gogue, Chambon ...), rider intervention (e.g. imposed attitude ["rassemblé", stooping, ...], gait used for a specific speed ...), horse's locomotory patterns (e.g. stride close to the ground vs. springy stride, extended vs. shortened paces ...) and/or environmental factors (e.g. quality of the track, outdoor vs. indoor exercise ...). More fundamental approaches include the study of the dynamic control of breath-by-breath VE and $\mathrm{VO}_{2}$ in relation to $\mathrm{HR}$, speed and gait (e.g. cardiorespiratory modifications at the transition from warm-up to maximal exercise achieved in field conditions and at the transition from exercise to active recovery [e.g. by trotting for a few minutes] ...). Such studies would probably provide additional key insights into equine sport medicine and would undoubtedly have applications in training management and conduct of competition in sport horses.

\section{Conclusions}

This study demonstrated that $\mathrm{VO}_{2}$ and cardiorespiratory parameters may be obtained in ridden saddle horses during a field trial. It also highlighted the necessity (1) to acclimatize horses to the face mask and test procedures to reduce influence of stress on the measured parameters, (2) to perform highly 
standardized tests, even in the field, to be able to interpret $\mathrm{VO}_{2}$ in the absence of $\mathrm{VO}_{2 \max }$ attainment and (3) to resort to other physiological parameters than the $\mathrm{VO}_{2 \max }$ to predict the athletic capacity of ridden horses under field conditions. This study opens new perspectives in the follow-up of sport horses especially in the evaluation of adaptations to training and athletic capacities in real field conditions.

\section{Acknowledgements}

The study was funded by the "Ministre de l'Agriculture et de la Ruralité de la Région wallonne" of Belgium. The authors thank Brigitte Deliège for her technical aid.

\section{Manufacturer's addresses}

$1 \mathrm{~K} 4 \mathrm{~b}^{2 \circledR}$, Cosmed SRL, Rome, Italy

2 Equimask ${ }^{\circledR}$, Cosmed SRL, Rome, Italy

3 Nafion ${ }^{\circledR}$ tubing, Perma Pure INC, New Jersey, USA

4 Polar Equine Transmitter ${ }^{\circledR}$, Polar Electro Europe BV, Fleurier, Switzerland

5 GPS Autolocate ${ }^{\top M}$, Garmin International INC, Kansas City, USA

6 Accutrend ${ }^{\circledR}$ Lactate, Roche, Basel, Switzerland

\section{References}

Art T., Anderson L., Woakes A. J., Roberts C., Butler P. J., Snow D. H. and Lekeux P. (1990): Mechanics of breathing during strenuous exercise in Thoroughbred horses. Respir Physiol 82, 279-294

Art T. and Lekeux P. (1993): Training-induced modifications in cardiorespiratory and ventilatory measurements in thoroughbred horses. Equine Vet J 25, 532-536

Art T. and Lekeux P. (1995): Ventilatory and arterial blood gas tension adjustments to strenuous exercise in standardbreds. Am J Vet Res 56, 1332-7

Art T., Votion D. and Lekeux P. (1995): Physiological measurements in horses after strenuous exercise in hot, humid conditions. Equine Vet J Suppl 20, 120-124

Art T., Duvivier D. H., van Erck E., de Moffart B., Votion D., Bedoret D., Lejeune J. P., Lekeux P. and Serteyn D. (2006): Validation of a portable equine metabolic measurement system. Equine Vet $J$ Suppl, in press

Betros C. L., McKeever K. H., Kearns C. F. and Malinowski K. (2002): Effects of ageing and training on maximal heart rate and $\mathrm{VO}_{2 \max }$. Equine Vet J Suppl 34, 100-105

Courouce A., Chretien M. and Valette J. P. (2002): Physiological variables measured under field conditions according to age and state of training in French Trotters. Equine Vet J 34, 91-97

Davie A. J., Priddle T. L. and Evans D. L. (2002): Metabolic responses to submaximal field exercise tests and relationships with racing performance in pacing Standardbreds. Equine Vet J Suppl 34, 1 12-115

Doyon K. H., Perrey S., Abe D. and Hughson R. L. (2001): Field testing of $\mathrm{VO}_{2}$ peak in cross-country skiers with portable breath-bybreath system. Can J Appl Physiol 26, 1-11
Duffield R., Dawson B., Pinnington H. C. and Wong P. (2004): Accuracy and reliability of a Cosmed $\mathrm{K}_{4} \mathrm{~b}^{2}$ portable gas analysis system. Sci Med Sport 7, 11-22

Eaton M. D., Evans D. L., Hodgson D. R. and Rose R. J. (1995): Effect of treadmill incline and speed on metabolic rate during exercise in thoroughbred horses. J Appl Physiol 79, 951-957

Evans D. L. and Rose R. J. (1988): Determination and repeatability of maximum oxygen uptake and other cardiorespiratory measurements in the exercising horse. Equine Vet J 20, 94-8

Gauvreau G. M., Staempfli H., McCutcheon L. J., Young S. S. and McDonell W. N. (1995): Comparison of aerobic capacity between racing standardbred horses. J Appl Physiol 4, 1447-1451

Harkins J. D., Beadle R. E. and Kamerling S. G. (1993): The correlation of running ability and physiological variables in thoroughbred racehorses. Equine Vet J 25, 53-60

Hoppeler H. and Weibel E. R. (1998): Limits for oxygen and substrate transport in mammals. J Exp Biol 201, 1051-1064

Jones J. H. and Lindstedt S. L. (1993): Limits to maximal performance. Annu Rev Physiol 55, 547-569

Kobayashi M., Kuribara K. and Amada A. (1999): Application of $V_{200}$ values for evaluation of training effects in the young thoroughbred under field conditions. Equine Vet J Suppl 30, 159-162

Laconi P., Melis F., Crisafulli A., Sollai R., Lai C. and Concu A. (1998): Field test for mechanical efficiency evaluation in matching volleyball players. Int J Sports Med 19, 52-55

Langsetmo I., Weigle G. E., Fedde M. R., Erickson H. H., Barstow T. J. and Poole D. C. (1997): $\mathrm{VO}_{2}$ kinetics in the horse during moderate and heavy exercise. J Appl Physiol 83, 1235-1241

McDonough P., Kindig C. A., Hildreth T. S., Behnke B. J., Erickson H. H. and Poole D. C. (2002a): Effect of body incline on cardiac performance. Equine Vet J Suppl 34, 506-509

McDonough P., Kindig C. A., Ramsel C., Poole D. C. and Erickson H. $H$. (2002b): The effect of treadmill incline on maximal oxygen uptake, gas exchange and the metabolic response to exercise in the horse. Exp Physiol 87, 499-506

Ohmura H., Hiraga A., Matsui A., Aida H., Inove Y., Asai Y. and Jones J. H. (2002): Physiological responses of young Thoroughbreds during their first year of race training. Equine Vet J Suppl 34, 140-146

Poole D. C. (2004): Current concepts of oxygen transport during exercise. Equine and Comparative Exercise Physiol 1, 5-22

Poole D. C, David C.; Kindig C. A., Behnke B. J. and Jones A. M. (2004): Current concepts of oxygen transport during exercise. Equine and Comparative Exercise Physiol 2, 1-15

Seeherman H. J. and Morris E. A. (1990): Application of a standardised treadmill exercise test for clinical evaluation of fitness in 10 thoroughbred racehorses. Equine Vet J Suppl 9, 26-34

Thomas C., Hanon C., Perrey S., Le Chevalier J. M, Couturier A. and Vandewalle H. (2005): Oxygen uptake response to an 800-m running race. Int J Sports Med 26, 268-273

Dr. Dominique-Marie Votion

Equine Clinic

Faculty of Veterinary Medicine

University of Liège, Sart Tilman

Boulevard de Colonster, Bat. B4 1

4000 Liège

Belgium

dominique.votion@ulg.ac.be

\title{
Berlin Equine Veterinary Congress
}

\author{
5.-8. Juli 2007
}

